\title{
Pengaruh Lama Perendaman Biji Kedelai (Glycine max L.Merr) terhadap Karakteristik Organoleptik Susu Kedelai
}

\section{The Effect of Soybean (Glycine max L.Merr) Soaking to Soya Milk Organoleptic Characteristics}

\author{
Mika Margareta*, Maryani \\ Balai Pelatihan Pertanian Lampung, Lampung, Indonesia \\ *email: mikamargareta110389@gmail.com
}

\begin{tabular}{ll}
\hline I N F O A R T I K E L & \multicolumn{1}{c}{ A B S T R A K } \\
\hline $\begin{array}{l}\text { Sejarah artikel: } \\
\text { Dikirim 13 Februari 2021 } \\
\text { Diterima 25 April 2021 }\end{array}$ & $\begin{array}{l}\text { Kedelai (Glycine max (L) Merr.) merupakan komoditas kacang-kacangan dengan } \\
\text { Terbit 26 April 2021 }\end{array}$ \\
& $\begin{array}{l}\text { kandungan protein nabati yang tinggi, sumber lemak, vitamin, dan mineral. Salah } \\
\text { langu yang kuat dan mouthfeel berkapur. Aroma langu pada susu kedelai dapat } \\
\text { dikurangi bahkan dihilangkan dengan mengaplikasikan teknik pengolahan yang }\end{array}$ \\
\hline Kata kunci: & benar. Salah satu langkah penting dalam mengolah kedelai menjadi susu kedelai \\
kedelai & adalah merendam biji kedelai. Penelitian yang berhubungan dengan perendaman \\
perendaman & kedelai untuk susu kedelai jarang ditemukan. Tujuan penelitian ini adalah \\
susu kedelai & mengetahui pengaruh lama perendaman biji kedelai terhadap karakteristik \\
& organoleptik susu kedelai sehingga dihasilkan susu kedelai yang baik \\
& penerimaannya dengan menggunakan rancangan percobaan Rancangan Acak \\
& Lengkap (RAL) dengan tiga perlakuan lama perendaman biji kedelai, yaitu 6 jam, \\
& 12 jam, dan 24 jam. Penelitian menghasilkan bahwa lama perendaman biji kedelai \\
Keywords: & hanya memberikan pengaruh terhadap tingkat kesukaan rasa dan penerimaan \\
soybean & keseluruhan susu kedelai. Selain itu, lama perendaman biji kedelai terbaik adalah \\
soya milk & selama 12 jam karena mampu memberikan pengaruh tingkat kesukaan rasa dengan \\
& penerimaan tertinggi dan paling berbeda dibanding perlakuan lain dengan skor \\
& penilaian kesukaan agak suka serta memberikan nilai rata-rata tingkat kesukaan \\
& tertinggi pada semua parameter.
\end{tabular}
$A B S T R A C T$

Soybeans (Glycine max (L) Merr.) are legumes that contain high vegetable protein, fat source, vitamins, and minerals. One of the products is soy milk. Soy milk has a strong beany flavour and a chalky mouthfeel. The flavour of soybeans in soy milk can be reduced by applying the appropriate processing techniques. One of the important steps in processing soybeans into soy milk is to soak soybeans. Studies

Kutipan format APA: Margareta, M. (2021). Pengaruh Lama Perendaman Biji Kedelai (Glycine max L.Merr) terhadap Karakteristik Organoleptik Susu Kedelai. AgriHumanis: Journal of Agriculture and Human Resource Development Studies, 2(1) 9-13. related to soaking soybeans to soy milk are rarely found. The purpose of this study was found out the long-lasting influence of soybean to the organoleptic characteristics of soy milk so that the soy milk is produced by its acceptance (good acceptance) by using a completely randomized design with three treatments of soybean soaking long as follows, 6 hours, 12 hours, and 24 hours. The organoleptic data was carried out with ANOVA method at $\alpha=5 \%$ and followed by DMRT. The results showed that long soaking the soybean only affected the level of taste and overall acceptance of soy milk. In addition, the best soaking time of soybean was 12 hours because it was able to influence the taste level of flavor with the highest acceptance and the most distinct acceptance compared to other treatment with a preferred assessment score and gave the highest value of the favorite level on all parameters.

\section{PENDAHULUAN}

Kedelai (Glycine max (L) Merr.) merupakan komoditas jenis kacang-kacangan dengan kandungan protein tertinggi mencapai 40\% (Arora et al., 2018). Kedelai adalah sumber nutrisi yang bermanfaat bagi kesehatan terutama karena kandungan fitokemikalnya yang berfungsi sebagai 
antioksidan (Colletti et al., 2020) . Sebagian besar pengolahan komoditas ini adalah menjadi produk makanan dan minuman. Produk minuman yang sudah dikenal oleh masyarakat adalah susu kedelai.

Susu kedelai adalah hasil pengolahan biji kedelai yang berbentuk cairan (liquid) berwarna putih yang mempunyai kenampakan dan konsistensi hampir menyerupai susu sapi (Adebayo, et.al., 2008). Beberapa keunggulan susu kedelai yaitu harganya terjangkau, dapat dikonsumsi untuk penderita lactose intolerant dan diabetes mellitus, dan mudah serta murah dalam proses pembuatannya menjadikan susu kedelai berperan penting dalam pola konsumsi masyarakat terutama di daerah negara berkembang (Koswara, 2006). Kandungan gizi dalam 8 oz susu kedelai murni adalah 140 g Kalori, 4 g lemak, 14 g karbohidrat, $120 \mathrm{~g}$ sodium, dan $80 \mathrm{~g}$ kalsium serta $10 \mathrm{~g}$ protein yang sama jumlahnya dengan susu sapi namun dengan profil asam amino yang berbeda (Dauda, 2014).

Susu kedelai memiliki aroma langu yang kuat, berpasir dan mouthfeel berkapur (Adawiyah, et.al., 2018). Aroma langu pada susu kedelai dapat dikurangi bahkan dihilangkan dengan mengaplikasikan teknik pengolahan yang benar. Proses pengolahan susu kedelai dapat diproduksi secara tradisional dengan cara mencuci biji kedelai, merendam, menggiling dengan penambahan air, menyaring dan memanaskan ekstrak (susu kedelai). Salah satu langkah penting dalam mengolah kedelai menjadi susu kedelai adalah merendam biji kedelai (Toda et al., 2001). Penelitian yang berhubungan dengan perendaman kedelai untuk susu kedelai masih jarang ditemukan. Penelitian tentang perendaman biji kedelai sebagian besar adalah pada produk selain susu kedelai. Pada proses pembuatan tempe, perendaman biji kedelai memberikan pengaruh pada tekstur biji kedelai akibat penyerapan air selama perendaman (Vishwanathan, et al., 2011). Selain itu, Pan dan Tangratanavale (2003) menyatakan bahwa perendaman biji kedelai menyebabkan perubahan karakteristik tekstur dan membantu pengekstraksian protein kedelai.

Tujuan penelitian ini adalah mengetahui pengaruh lama perendaman biji kedelai terhadap karakteristik organoleptik susu kedelai sehingga dihasilkan susu kedelai yang baik penerimaannya (good acceptance). Penelitian lain yang berhubungan dengan organoleptik susu kedelai banyak dilakukan diantaranya untuk mengetahui pengaruh varietas kacang kedelai (Nirmagustina, 2013) dan penambahan air (Picauly et al., 2015) dengan parameter yang diamati adalah warna, aroma dan rasa susu kedelai. Namun, pada penelitian ini terdapat parameter uji organoleptik yang ditambahkan yaitu penerimaan keseluruhan.

Susu kedelai diproduksi dengan ekstraksi menggunakan air panas atau air dingin. Air panas (80$100 \mathrm{oC}$ ) digunakan pada saat penggilingan yang tujuannya adalah menginaktifkan enzim lipoksigenase yang dapat menyebabkan beany flavor (aroma langu), sedangkan proses ekstraksi dengan air dingin jarang dilakukan kecuali oleh negara oriental yang tidak mempermasalahkan bau langu (Berk, 1992). Oleh karena itu, pengolahan susu kedelai dilakukan dengan metode ekstraksi pada suhu panas

\section{METODE}

\subsection{Alat dan Bahan}

Alat yang digunakan dalam pembuatan susu kedelai meliputi baskom, kompor, panci, saringan, blender, gelas ukur, termometer dan timbangan. Sementara itu, penelitian ini menggunakan bahan-bahan diantaranya biji kedelai kuning impor yang dibeli di pasar lokal, air, gula pasir, garam dan vanili.

\subsection{Pembuatan Susu Kedelai}

Penelitian ini dilaksanakan di Laboratorium Pengolahan Hasil Pertanian Balai Pelatihan Pertanian Lampung pada bulan Mei Tahun 2020. Pembuatan susu kedelai dilakukan dengan memodifikasi metode Picauly et al., (2015). Biji kedelai disortir, kemudian dicuci hingga bersih. Setelah itu direbus selama 15 menit dengan perbandingan air 1:3. Selanjutnya, air rebusan dipisahkan dengan menyaring biji kedelai menggunakan saringan. Biji kedelai kemudian direndam dengan tingkat perlakuan yaitu 6 jam, 12 jam dan 24 jam dengan perbandingan biji kedelai dan air 1:3. Setelah itu, air rendaman dibuang dan biji kedelai dicuci serta dikupas kulit arinya. Biji kedelai yang sudah bersih dihaluskan dengan blender dengan penambahan air panas dengan suhu $90^{\circ} \mathrm{C}$ dengan perbandingan 1:8. Bubur kedelai encer selanjutnya disaring untuk mendapatkan susu kedelai. Kemudian susu kedelai tersebut ditambahkan gula dengan konsentrasi $4 \%, 0,55 \%$ untuk garam, dan $0,15 \%$ untuk vanili dalam setiap perlakuan. 


\subsection{Pengamatan}

Pengamatan dilakukan menggunakan uji organoleptik dengan menggunakan uji skala hedonik (tingkat kesukaan). Uji organoleptik dilakukan dengan meminta panelis memberikan penilaian terhadap sampel susu kedelai. Pertama kali panelis diminta untuk mencicipi susu kedelai. Diantara proses pencicipan sampel, panelis diminta untuk minum air sebagai penetral. Selanjutnya, panelis menilai susu kedelai berdasarkan tingkat kesukaan yang terdiri dari aroma, rasa, warna, dan penerimaan keseluruhan dengan menggunakan skala hedonik sebanyak 7 tingkat, yaitu sangat tidak suka (1) hingga sangat suka (7) (Kartika et al., 1988). Sampel diberikan kepada 15 panelis tidak terlatih secara acak dengan rentang usia beragam dari 24 tahun hingga 50 tahun. Jenis penelitian digunakan dalam bentuk eksperimen murni dengan 3 kali pengulangan dalam bentuk Rancangan Acak Lengkap (RAL).

\subsection{Analisis Data}

Pengolahan data uji hedonik dilakukan dengan analisis ragam (Anova) untuk melihat pengaruh perlakuan parameter yang diuji. Jika pengaruh perlakuan nyata, yaitu Fhit $\geq(p<0,05)$ Ftabel maka dilanjutkan dengan uji DMRT (Duncan Multiple Range Test) untuk mengetahui perbedaan antar pelakukan (Nirmagustina dan Rani, 2013).

\section{HASIL DAN PEMBAHASAN}

Data hasil analisis ragam dapat dilihat pada Tabel 1. Parameter yang dianalisa terdiri dari aroma, warna, rasa, dan penerimaan keseluruhan yang menghasilkan analisis ragam berbeda. Berdasarkan hasil analisis ragam (Tabel 1) menunjukkan bahwa lama perendaman berpengaruh nyata terhadap parameter rasa dan penerimaan keseluruhan, sedangkan parameter aroma dan warna susu kedelai tidak dipengaruhi oleh lama perendaman biji kedelai.

Tabel 1. Analisis ragam pengaruh lama perendaman Biji Kedelai terhadap Karakteristik Organoleptik Susu Kedelai

\begin{tabular}{ll}
\hline \multicolumn{1}{c}{ Parameter } & $P$-value \\
\hline Aroma & $0,448^{\mathrm{ns}}$ \\
Warna & $0,448^{\mathrm{ns}}$ \\
Rasa & $0,020^{* *}$ \\
Penerimaan Keseluruhan & $0,014^{* *}$ \\
\hline
\end{tabular}

Keterangan:

** : berpengaruh sangat nyata $(\mathrm{p}<0,05)$

ns : tidak berpengaruh nyata $(\mathrm{p}>0,05)$

Berdasarkan data pada Tabel 1 dinyatakan bahwa $p$-value 0,448 lebih besar dari 0,05 (p>0,05) untuk parameter aroma. Dengan demikian, dapat diketahui bahwa perendaman biji kedelai tidak berpengaruh nyata terhadap aroma susu kedelai. Sama halnya dengan parameter aroma, $p$-value warna adalah 0,448 lebih besar dari 0,05 ( $>>0,05$ ) sehingga tingkat kesukaan warna susu kedelai tidak dipengaruhi lama perendaman biji kedelai. Adapun, paramater rasa dan penerimaan keseluruhan susu kedelai dipengaruhi oleh lama perendaman karena nilai $p$-value keduanya lebih kecil dari $0,05(\mathrm{p}<0,05)$, yaitu 0,020 dan 0,014 .

Parameter rasa dan penerimaan keseluruhan selanjutnya dilakukan uji DMRT. Tabel 2 menunjukkan tingkat kesukaan dan hasil uji DMRT keempat parameter organoleptik. Oleh karena parameter aroma dan warna tidak dipengaruhi lama perendaman kedelai, maka hasil uji DMRT kedua parameter tersebut tidak berbeda pula. Akan tetapi, nilai rata-rata tingkat kesukaan tertinggi untuk parameter aroma dan warna adalah pada perlakuan lama perendaman 12 jam, yaitu 5,13 dan 5,4.

Tabel 2. Tingkat kesukaan susu kedelai

\begin{tabular}{lcccc}
\hline \multirow{2}{*}{ Perlakuan } & \multicolumn{2}{c}{ Nilai Rata-Rata } \\
\cline { 2 - 5 } & Aroma & Warna & Rasa & $\begin{array}{c}\text { Penerimaan } \\
\text { Keseluruhan }\end{array}$ \\
\hline 6 jam & $4,51^{\mathrm{a}}$ & $5,2^{\mathrm{a}}$ & $4,8^{\mathrm{a}}$ & $4,53^{\mathrm{a}}$ \\
12 jam & $5,13^{\mathrm{a}}$ & $5,4^{\mathrm{a}}$ & $5,13^{\mathrm{b}}$ & $5,16^{\mathrm{b}}$ \\
24 Jam & $4,24^{\mathrm{a}}$ & $3,93^{\mathrm{a}}$ & $3,67^{\mathrm{a}}$ & $4,4^{\mathrm{a}}$ \\
\hline
\end{tabular}

Keterangan : Angka yang diikuti oleh huruf notasi sama tidak berbeda nyata pada uji DMRT (5\%) 
Hasil uji DMRT menunjukkan bahwa parameter rasa dengan perlakuan perendaman biji kedelai selama 12 jam menunjukkan hasil terbaik yang berbeda nyata dengan perlakuan lain (Tabel 2.). Rasa adalah bentuk sensasi dari kombinasi bahan pembentuk dan komposisinya yang dirasa oleh indra pengecap. Rasa menjadi pendukung kualitas suatu produk. Susu kedelai akan diterima oleh konsumen jika rasanya sesuai. Panelis lebih menyukai susu kedelai dengan lama perendaman 12 jam karena tidak asam dan rasa khas kedelainya tidak menyengat. Tabel 2 juga menunjukkan bahwa nilai tingkat kesukaan rasa terendah adalah pada perlakuan 24 jam, yaitu 3,67. Menurut (Suhaidi, 2003), perendaman biji kedelai yang terlalu lama akan meningkatkan kandungan kadar air dan rendahnya protein sehingga rasa kurang disukai dan aroma menjadi kurang khas. Selain itu, menurut panelis, semakin lama perendaman dapat menimbulkan rasa asam. Hal ini disebabkan oleh tumbuhnya bakteri asam laktat sehingga peningkatan kadar asam susu kedelai akibat aktivitas bakteri asam laktat yang merubah glukosa menjadi asam laktat (Lumowa dan Nurani, 2014). Akan tetapi, perendaman yang terlalu cepat juga akan menimbulkan aroma yang kurang disukai karena bau langu (beany flavor) akibat kadar protein yang tinggi.

Hasil Uji DMRT menunjukkan bahwa parameter penerimaan keseluruhan dengan perlakuan perendaman biji kedelai selama 12 jam memiliki rerata tingkat kesukaan terbaik yang berbeda nyata dengan perlakuan lain Tingkat penerimaan keseluruhan panelis diduga dipengaruhi oleh bermacam faktor sehingga berdampak ada keutuhan penerimaan. Berdasarkan Tabel 2 nilai tingkat kesukaan penerimaan keseluruhan perlakuan perendaman 12 jam memiliki skor tertinggi, yaitu 5,16. Hal ini menunjukkan bahwa penerimaan keseluruhan dengan perendaman biji kedelai 12 jam lebih disukai dibandingkan dengan perlakuan lain. Penerimaan keseluruhan adalah penilaian terakhir yang diamati oleh panelis. Penerimaan keseluruhan merupakan gabungan dari warna, aroma, dan rasa (Triyono, 2010). Penilaian secara deskriptif susu kedelai dengan tingkat penerimaan terbaik yaitu dengan perlakuan perendaman biji kedelai 12 jam adalah memiliki warna putih tidak bening, aroma tidak bau khas kedelai (langu) dan rasa kurang khas kedelai.

\section{KESIMPULAN DAN SARAN}

\subsection{Kesimpulan}

Berdasarkan hasil penelitian disimpulkan bahwa lama perendaman biji kedelai tidak memberikan pengaruh yang nyata terhadap tingkat kesukaan aroma dan warna, sedangkan parameter tingkat kesukaan rasa dan penerimaan keseluruhan susu kedelai memberikan hasil yang berbeda nayata untuk perlakuan lama perendaman biji kedelai. Susu kedelai dengan perlakuan perendaman 12 jam menunjukkan hasil terbaik dengan nilai kesukaan tertinggi untuk parameter rasa dan penerimaan keseluruhan, yaitu 5,13 dan 5,16 dengan skor penilaian kesukaan agak suka.

\subsection{Saran}

Diperlukan penelitian lanjutan untuk mengetahui karakteristik kimia dan organoleptik susu kedelai dengan kombinasi perlakuan lama perendaman biji kedelai dan lama blanching sehingga diperoleh mutu susu kedelai terbaik baik secara organoleptik maupun kimiawi.

\section{DAFTAR PUSTAKA}

Adawiyah, D.R., Andarwulan, N., Triana, R.N., Agustin, D., \& Gitapratiwi, D. (2018). Evaluasi Perbedaan Varietas Kacang Kedelai Terhadap Mutu Produk Susu Kedelai. Jurnal Mutu Pangan, 5(1): 10-16.

Adebayo T.B., Adegoke AA, Akinjogunla OJ. (2008). Microbial And Physico-Chemical Quality Of Powdered Soymilk Samples In Akwa Ibom, South Southern Nigeria. African Journal of Biotechnology, 13.

Arora, A, Dogra, A, Goyal, B. (2018). Production of Soymilk and Comparative Analysis with Cow Milk. Research J. Pharm. And Tech., 11(10) ,4515-4520.

Berk Z. (1992). Technology of Production Of Edible Flours And Protein Products From Soybeans. Retrieved From FAO Agricultural Services Bulletin no. 97: http://www.fao.org/docrep/t0532e/t0532e00.htm (Diakses pada tanggal 1 Juli 2020).

Colletti, A., Attrovio, A., Boffa., L., Mantegna, S., \& Cravotto, G. (2020). Valorisation of By-Products from Soybean (Glycine $\max$ (L.) Merr.) Processing. Molecules, 25, 2129. doi:10.3390/molecules25092129 
Dauda AO., Adegoke GO. (2014). Preservation of Some Physico Chemical Properties of SoymilkBased Juice with Aframomum Danielli Spice Powder. American Journal of Food Science and Technology. 2(4), 116-121.

Endrasari R., Nugrasari D. (2012). Pengaruh Berbagai Cara Pengolahan Sari Kedelai Terhadap Penerimaan Organoleptik. Dalam: Prosiding Seminar Nasional Optimalisasi Pekarangan. Semarang (ID): Undip Press.

Kartika, Hastuti BP, Supartono W. (1988). Pedoman Uji Inderawi Bahan Pangan. Yogyakarta: UGM Press.

Koswara, S. (2006). Teknologi Pengolahan Kedelai : Menjadikan Makanan Bermutu. Bogor: Pustaka Sinar Harapan.

Lumowa, S.V.T., Nurani, I. (2014). Pengaruh Perendaman Biji Kedelai ((Glycine max, L. Merr) Dalam Media Perasan Kulit Nanas (Ananas comosus (Linn.) Merrill) Terhadap Kadar Protein Pada Pembuatan Tempe. Jurnal EduBio Tropika, 2(2):187-250.

Nirmagustina, D.E., Rani, H. (2013). Pengaruh Jenis Kedelai dan Jumlah Air Terhadap Sifat Fisik, Organoleptik, dan Kimia Susu Kedelai.

Pan Z., \& Tangratanavalee W. (2003). Characteristics Of Soybean As Affected By Soaking Conditions. LWT Food Sci Technol, 36, 143-151.

Picauly, P., Talahatu, J., \& Mailoa, M. (2015). Pengaruh Penambahan Air Pada Pengolahan Susu Kedelai. Agritekno: JUrnal Teknologi Pertanian. 4(1), 8-12.

Suhaidi, I. (2003). Pengaruh Lama Perendaman Kedelai dan Jenis Zat Penggumpal Terhadap Mutu Tahu. USU Digital Library.

Toda T, Sakamoto A, Takayanagi T, Yokotsura K. (2001). Changes in Isoflavone Compositions Soybean During Soaking Process. Food Sci Technol Res, 6, 314-319

Triyono, A. (2010). Mempelajari Pengaruh Meltodekstrin dan Susu Skim Terhadap Karakteristik Yoghurt Kacang Hijau. Subang: Balai Besar Pengembangan Teknologi Tepat Guna - LIPI.

Vishwanathan KH, Singh V, Subramanian R. (2011). Wet Grinding Characteristics Of Soybean For Soymilk Extraction. Journal of Food Engineering, 106:28-34. 
[Halaman ini sengaja dikosongkan] 